\title{
Refractory coeliac disease: About five cases
}

\author{
Bennani $\mathrm{G}^{1 *}$, Jahid $\mathrm{A}^{2}$, Benelberhdadi $\mathrm{I}^{1}$ and Ajana $\mathrm{F}^{\mathbf{1}}$ \\ ${ }^{1}$ Department of Diseases of the Digestive System, Medicine C, CHU IBN SINA-Souissi Med University, V-Rabat, Morocco \\ ${ }^{2}$ Department of Pathology, Ibn Sina University Hospital, Rabat, Morocco
}

\begin{abstract}
Refractory coeliac disease (RCD) is defined by persistent or recurrent malabsorptive symptoms and villous atrophy despite strict adherence to a gluten-free diet (GFD) for at least 6-12 months in the absence of other causes of non-responsive treated coeliac disease and overt malignancy. Symptoms are often severe and require additional therapeutic intervention besides a GFD. RCD can be classified as type 1 which usually improves after treatment with a combination of aggressive nutritional support, adherence to a GFD, and alternative pharmacological therapies. By contrast, clinical response to alternative therapies in RCD type 2 is less certain and the prognosis is poor. Severe complications such as ulcerative jejunitis and enteropathy-associated T cell lymphoma may occur in a subgroup of patients with RCD. The aim of this article is to describe the profile of patients with RCD, their management, and their evolution in a series of 284 patients with celiac disease.
\end{abstract}

\section{Introduction}

Refractory coeliac disease (RCD) is a rare complication of Celiac Disease (CD), defined by persistent malabsorption symptoms and villous atrophy despite adherence to a strict gluten-free diet for at least 6 to 12 months. RCD is classified as type I or type II (lymphoma in situ) based on the absence or presence of an aberrant intra-epithelial lymphocyte (IEL) population.

\section{Materials and methods}

We report 5 cases of RCD collected within our practice over a period of 24 years (1995 - 2018). All our patients benefit from a specialized consultation of celiac disease and a gluten-free diet analysis by a wellinformed dietician. Our goal is to describe the profile of patients with $\mathrm{RCD}$, their management, and their evolution.

\section{Result}

Out of 284 cases of celiac disease, 5 cases were complicated by RCD $(1.17 \%)$, including 4 men and 1 woman (sex ratio $=4)$, the mean age was 43.2 years with extremes between 21 and 72 years old. Initially the diagnosis of $\mathrm{CD}$ was posed on an array of clinical, biological, histologic, and serologic evidence. IEL rate varied between $35 \%$ to $70 \%$, and villous atrophy (AV) varied between partial and total. Serology was positive in 3 out of 5 cases.

The diet was initiated immediately after confirmation of the diagnosis of $\mathrm{CD}$, and the evolution was marked by a clinical and biological improvement that lasted between 12 and 18 months.

Our 5 patients with RCD have the following symptoms: severe chronic diarrhoea, weight loss with significant malnutrition, edema and leg paraesthesia.

The pathological result was: 4 patients had RCD type I sprue and 1 patient had RCD type II with ulcerative jejunitis.

As to the therapeutic management of these patients, three of them were put on budesonide and parenteral nutrition, one patient was lost of view and the last one is under investigation.
The evolution of patients on budesonide was marked by clinical and biological improvement in two patients, and death of the third by multiple location lymphoma.

\section{Discussion}

A small subgroup of patients with $\mathrm{CD}$ may be primarily or secondarily resistant to a well observed GFD due to an authentic refractory $\mathrm{CD}(\mathrm{RCD})$

Refractory celiac disease (RCD) refers to 2 distinct entities according to the normal (RCDI) or abnormal (RCDII) phenotype of intestinal intraepithelial lymphocytes [1]. Diagnosis requires specialized small bowel investigations (enteroscopy, small bowel imaging) and techniques (immunohistochemistry, molecular analysis, flow cytometry)

The real prevalence of RCD is unknown but probably rare because of the low number from major CD referral centres of RCD cases reported in the literature [2,3].

The incidence of CD complicated by RCD found in our series is $1.17 \%$ ( 5 of 284 ) which is close to the result found in the literature for example; A North American referral centre suggests a cumulative incidence of $1.5 \%$ for both RCDI and RCDII among patients with CD diagnosed in this centre [4]. In the Derby cohort, J. West and G. Holmes report approximately $0.7 \%$ of patients with $R C D$ with ulcerative jejunitis in series of 713 patients with CD [5].

$\mathrm{CD}$ affects two times as many women than men [6], consistent with the predominance of diagnosed CD in adult women. The predominance of disease in women diminishes somewhat in those patients with both RCD and EATL [7]. Unlike the result of our study where the predominance of RCD belongs to men 4 men against 1 woman.

${ }^{\star}$ Correspondence to: Ghita Bennani, Department of Diseases of the Digestive System, Medicine C, CHU IBN SINA-Souissi Med University, V-Rabat, Morocco, Tel: +212 5376-76464; E-mail: ghita_med5@yahoo.fr

Key words: refractory coeliac disease, gluten-free diet, therapeutic management

Received: April 06, 2020; Accepted: April 24, 2020; Published: April 27, 2020 
The age of diagnosis of RCD is often around 50 years old and rarely before 30 years of age [8]. In our study, the mean age was 43.2 years with extremes between 21 and 72 years old.

Diarrhoea, gastrointestinal disorders, anaemia, fatigue, and malaise are common [9]. The majority of patients with RCD are diagnosed because of the development of new symptoms or recurrence of diarrhoea. In our group patients with RCD have the following symptoms: severe chronic diarrhoea, weight loss with significant malnutrition, edema and leg paraesthesia

Hospitalization to monitor adherence to GFD and for parenteral nutrition was necessary for one patient with RCD because of severe weight loss, malnutrition, multiple nutritional deficiencies, and severe hypoproteinemia. udesonide $(9 \mathrm{mg} /$ day), Prednisone $(0.5-1 \mathrm{mg} / \mathrm{kg} /$ day), or a combination of prednisone and azathioprine $(2 \mathrm{mg} / \mathrm{kg} /$ day) are clinically effective to induce clinical remission and mucosal recovery in most patients with RCD type $1[10,11]$. Clinical response to steroids is observed in the majority of patients with RCD type 2, Other immunosuppressive drugs or biological modifiers have been used with some clinical benefit in steroid-dependent or steroid-refractory patients including cyclosporin, infliximab $(5 \mathrm{mg} / \mathrm{kg} /$ day $)$ and alemtuzumab $[12,13]$.

As to the therapeutic management of our patients, three of them were put on budesonide and parenteral nutrition, one patient was lost of view and the last one is under investigation.

Steroids improved clinical symptoms in most patients with either type of RCD with various histologic responses from $30 \%$ to $40 \%$ of cases to nearly $90 \%$ in a recent study using open capsule budesonide [14]. Prognosis of RCDII is worse than RCDI because of more severe malnutrition and an elevated risk of overt lymphoma [15]. Molecular analysis showed a polyclonal repertoire for RCDI. In contrast, the abnormal population characteristic of RCD type II is sought by 3 combined techniques in duodenal biopsies; The pathological result in our study was: 4 patients had RCD type I sprue and 1 patient had RCD type II with ulcerative jejunitis which is an entity often associated with this pathology [16]. Prognosis of refractory coeliac disease type II is poor because therapies are less effective and high risk of progression to enteropathy-type T-cell lymphoma [17].

Risk of lymphomatous complications was reported 4 times higher in patients without adherence to a GFD than compliant patients [18].

In our study, the evolution of patients on budesonide was marked by clinical and biological improvement in two patients, and death of the third by multiple location lymphoma

\section{Conclusion}

$\mathrm{RCD}$ is a rare complication of $\mathrm{CD}, \mathrm{RCD}$ type $\mathrm{I}$ is managed by a nutritional and pharmacological support, unlike RCD type II which is of poor prognosis.

\section{References}

1. Malamut G, Cellier C (2018) Refractory Celiac Disease. Gastroenterol Clinics North Am 48: 1-182.

2. Abdulkarim AS, Burgart LJ, See J, Murray JA (2002) Etiology of nonresponsive celiac disease: results of a systematic approach. Am J Gastroenterol 97: 2016-2021. [Crossref]

3. Leffler DA, Dennis M, Hyett B, Kelly E, Schuppan D, et al. (2007) Etiologies and predictors of diagnosis in nonresponsive celiac disease. Clin Gastroenterol Hepatol 5: 445-450. [Crossref]

4. Roshan B, Leffler DA, Jamma S, Melinda D, Sunil S, et al. (2011) The incidence and clinical spectrum of refractory celiac disease in a North American referral center. Am J Gastroenterol 106: 923-238. [Crossref]

5. West J (2009) Celiac disease and its complications: a time traveller's perspective Gastroenterol 136: 32-34. [Crossref]

6. Malamut G, Afchain P, Verkarre V, Lecomte T, Amiot A, et al. (2009) Presentation and long-term follow-up of refractory celiac disease: comparison of type I with type II. Gastroenterol 136: 81-90. [Crossref]

7. Rubio-Tapia A, Kelly DG, Lahr BD, Dogan A, Wu TT, et al. (2009) Clinical staging and survival in refractory celiac disease: a single center experience. Gastroenterol 136: 99-107. quiz 352-353. [Crossref]

8. Al-Toma A, Verbeek WH, Hadithi M, von Blomberg BM, Mulder CJ (2007) Survival in refractory coeliac disease and enteropathy-associated T-cell lymphoma: retrospective evaluation of single-centre experience. Gut 56: 1373-1378. [Crossref]

9. Al-toma A, Verbeek WH, Mulder CJ (2007) The management of complicated celiac disease. Dig Dis 25: 230-236. [Crossref]

10. Cellier C, Delabesse E, Helmer C, Patey N, Matuchansky C, et al. (2000) Refractory sprue, coeliac disease, and enteropathy-associated T-cell lymphoma. French Coeliac Disease Study Group. Lancet 356: 203-208. [Crossref]

11. Cellier C, Cerf-Bensussan N (2006) Treatment of clonal refractory celiac disease or cryptic intraepithelial lymphoma: A long road from bench to bedside. Clin Gastroenterol Hepatol 4: 1320-1321.

12. Verbeek WH, Mulder CJ, Zweegman S (2006) Alemtuzumab for refractory celiac disease. N Engl J Med 355: 1396-1397. author reply 1397. [Crossref]

13. Maurino E, Niveloni S, Chernavsky A, Pedreira S, Mazure R, et al. (2002) Azathioprine in refractory sprue: results from a prospective, open-label study. Am J Gastroenterol 97: 2595-602. [Crossref]

14. Malamut G, Afchain P, Verkarre V, Lecomte T, Amiot A, et al. (2009) Presentation and long-term follow-up of refractory celiac disease: comparison of type I with type II. Gastroenterology 136: 81-90. [Crossref]

15. Maurino E, Niveloni S, Chernavsky AC, Sugai E, Vazquez H, et al. (2006) Clinical characteristics and long-term outcome of patients with refractory sprue diagnosed at a single institution. Acta Gastroenterol Latinoam 36: 10-22. [Crossref]

16. Ashton-Key M, Diss TC, Pan L, Du MQ, Isaacson PG (1997) Molecular analysis of T-cell clonality in ulcerative jejunitis and enteropathy-associated T-cell lymphoma. $\mathrm{Am}$ J Pathol 151: 493-498. [Crossref]

17. Abdallah H, Leffler D, Dennis M (2007) Refractory celiac disease. Curr Gastroenterol Rep 9: 401-405. [Crossref]

18. Holmes GK, Prior P, Lane MR, Pope D, Allan RN (1989) Malignancy in coeliac disease-effect of a gluten free diet. Gut 30: 333-338. [Crossref]

Copyright: (C2020 Bennani G. This is an open-access article distributed under the terms of the Creative Commons Attribution License, which permits unrestricted use, distribution, and reproduction in any medium, provided the original author and source are credited. 